\title{
Rekombinan Vascular Endothelial Growth Factor-121 Menekan Ekspresi Heat Shock Protein-70 pada Plasenta Mencit Model Preeklampsia
}

\author{
(VASCULAR ENDOTHELIAL GROWTH FACTOR-121 RECOMBINANT \\ DEPRESSIS HEAT SHOCK PROTEIN-7O EXPRESSION \\ IN PREECLAMPSIA MICE PLACENTA MODEL)
}

\author{
Sri Sulistyowati, Lungguk Helen Alfian Tanjung, \\ Supriyadi Hari Respati, Eric Edwin Yuliantara, Soetrisno \\ Bagian Obsteterik dan Ginekologi, Fakultas Kedokteran, \\ Universitas Sebelas Maret/ RSUD Dr. Moewardi Surakarta. \\ Jl. Kolonel Sutarto 132, Surakarta, Jawa Tengah, Indonesia. \\ Telp./ Fax: 0271 665145; Email: elis_spog@yahoo.co.id
}

\begin{abstract}
ABSTRAK
Preeklampsia masih merupakan penyebab utama morbiditas dan mortalitas maternal dan perinatal. Stres oksidatif yang terjadi pada preeklampsia menyebabkan Heat Shock Protein-70 (HSP70) meningkat. Vascular Endothelial Growth Factor (VEGF) sebagai terapi diduga dapat memperbaiki stres oksidatif. Penelitian ini bertujuan untuk mengetahui peran VEGF-121 rekombinan terhadap ekspresi HSP-70 pada plasenta mencit model preeklampsia dengan metode eksperimental analitik (ekspanatorik) dilakukan di Kandang Hewan Percobaan, Fakultas Kedokteran Hewan, Universitas Airlangga. Sampel berjumlah 30 mencit dibagi kedalam tiga kelompok yaitu 10 mencit bunting normal, 10 mencit model preeklampsia, dan 10 mencit model preeklampsia dengan terapi VEGF-121 rekombinan. Pada hari ke-16 kebuntingan semua mencit dilakukan pemeriksaan ekspresi HSP-70 pada plasentanya dengan metode Immunohistokimia. Data dianalisis menggunakan uji Kruskall-Wallis program SPSS. Rataan ekspresi HSP-70 pada kelompok bunting normal 1,69 $\pm 0,68$, kelompok model preeklampsia 3,50 $\pm 0,95$ dengan nilai $\mathrm{p}=0.00$, dan rataan ekspresi HSP-70 kelompok model preeklampsia dengan terapi VEGF-121 rekombinan 2,24 $\pm 0,84$ dengan nilai $\mathrm{p}=0.00$. VEGF-121 rekombinan berperan menurunkan ekspresi HSP-70 pada plasenta mencit model preeklampsia.
\end{abstract}

Kata-kata kunci: VEGF-121 rekombinan; HSP-70; preeklampsia

\begin{abstract}
Preeclampsia has remained a major cause of morbidity and maternal-perinatal mortality. Oxidative stress that occurs in preeclampsia increases HSP-70 expression. Therefore, VEGF therapy is expected to recover this oxidative stress. This research aimed to determine the role of VEGF-121 recombinant on HSP-70 expression in mice model of preeclampsia. This research was an explanatory study conducted at Animal Cage Experiment, Faculty of Veterinary Medicine, Airlangga University. The samples were 30 mice that were divided into 3 groups, namely a group of 10 normal pregnant mice, a group of 10 mice model of preeclampsia, and a group of 10 mice model of preeclampsia with VEGF-121 recombinant therapy. On the $16^{\text {th }}$ day of gestation, HSP-70 expressions in the placenta of all mice were examined using immunohistochemical methods. The data were analyzed using Kruskall-Wallis test of SPSS program. The mean of HSP-70 expression in normal pregnancy group was $1.69 \pm 0.68$, in preeclampsia model group was $3.50 \pm 0.95$ with $p=0.00$, and in preeclampsia model group with VEGF-121 recombinant therapy was 2.24 \pm 0.84 with $p=0.00$. In short, VEGF-121 recombinant has a role in lowering HSP-70 expression in mice placenta model of preeclampsia.
\end{abstract}

Keywords: VEGF-121 recombinant; HSP-70; preeclampsia 


\section{PENDAHULUAN}

Preeklampsia merupakan penyebab utama morbiditas dan mortalitas maternal maupun perinatal dengan karakteristik adanya hipertensi dan proteinuria pada usia kehamilan di atas 20 minggu dan terdapat kelainan yang kompleks termasuk komponen maternal dan plasental (Sahin et al., 2015; Sheikhi et al., 2015). Ghulmiyyah dan Sibai (2012) menyatakan bahwa preeklampsia merupakan sindrom klinis dengan karakteristik onset baru dari hipertensi dan proteinuria setelah 20 minggu usia kehamilan/gestasi pada wanita yang sebelumnya normotensi.

Prevalensi kejadian preeklampsia sekitar 5$15 \%$ dari keseluruhan kehamilan di dunia. Kasus hipertensi dalam kehamilan termasuk preeklampsia ditemukan dalam jumlah yang cenderung meningkat dan merupakan komplikasi medis tersering dalam kehamilan. Sekitar 70\% wanita yang didiagnosis hipertensi dalam kehamilan merupakan kasus preeklampsia (Han et al., 2014). Tiap tahunnya diperkirakan ada 50.000 wanita yang meninggal karena preeklampsia (Shamsi et al., 2013). Di Indonesia 30-40\% kasus preeklampsia menjadi penyebab kematian ibu hamil dan 30-50\% menjadi penyebab kematian perinatal. Di Rumah Sakit Umum Daerah (RSUD) Dr. Moewardi, Surakarta kematian Ibu hamil yang disebabkan oleh preeklampsia yaitu 19 orang dari 30 Ibu hamil yang meninggal pada tahun 2012 dan pada tahun 2013 terdapat 12 orang Ibu hamil meninggal karena preeklampsia dari $21 \mathrm{Ibu}$ hamil yang meninggal (Sulistyowati et al., 2016).

Saat ini telah berkembang bukti bahwa ketidakseimbangan antara faktor proangiogenik plasental gtowth factor (PlGF), vascular endothelial growth factor (VEGF) dengan faktor antiangiogenik soluble Fms-like tyrosine kinase1 (sFlt-1) dan soluble endoglin (sEng), diduga terlibat dalam patogenesis preeklampsia. Soluble Fms-like tyrosine kinase-1 merupakan antagonis dari PlGF dan VEGF yang terikat pada reseptor yang sama. Konsentrasi PlGF dan VEGF menurun pada preeklampsia (Sahin et al., 2015; Creasy et al., 2014; Tal, 2012). Kadar sFlt-1 meningkat secara gradual pada preeklampsia antara 25-28 minggu dan meningkat 5-6 minggu sebelum onset preeklampsia (Muller dan Schiffer, 2014). Meningkatnya sFlt-1 berhubungan dengan manifestasi klinis preeklampsia. Senyawa sFlt-1 menetralisir ligannya, menurunkan konsentrasi VEGF dan PlGF dalam sirkulasi (Sheikhi et al., 2015). Saat ini pengukuran kadar serum sFlt-1 dan rasio sFlt-1/ PlGF dapat digunakan sebagai penduga/ prediktor untuk preeklampsia. Rasio sFlt-1/ PlGF yang lebih kecil dari 38 dapat digunakan sebagai prediktor terjadinya preeklampsia (Zeisler et al., 2016).

Pada kehamilan normal terjadi stres oksidatif ringan dan sistem antioksidan bekerja dari awal kehamilan sampai dengan aterm sehingga tidak terjadi komplikasi kehamilan. Pada preeklampsia terjadi plasentasi yang tidak sempurna termasuk tidak sempurnanya remodeling arteria spiralis dan invasi trofoblas di desidua yang menyebabkan berkurangknya perfusi darah, hipoksia/iskemia, dan diikuti terjadinya stres oksidatif (Hansson et al., 2015). Stres oksidatif pada preeklampsia dapat terjadi baik pada sirkulasi maternal dan atau pada plasenta (Sheikhi et al., 2015). Respons adanya iskhemi plasenta yaitu meningkatnya reactive oxygen species (ROS) yang merupakan faktor terjadinya disfungsi endotel pada preeklampsia baik secara langsung pada endotelium ataupun secara sekunder pada pathway down regulation dari vasoaktif signaling molekul. Senyawa ROS pada endotelium bisa terjadi karena menurunnya VEGF pada maternal (George dan Granger, 2011). Patofisiologi preeklampsia belum jelas tetapi ketidakseimbangan ROS dan antioksidan penting sebagai salah satu faktor. Stres oksidatif (ROS) diduga kuat berkontribusi terhadap disfungsi endotel pada preeklampsia. Senyawa ROS mendorong lipid peroksida menyebabkan stres protein, sehingga HSP-70 meningkat (Ekambaram, 2011).

Untuk mempertahankan keadaan homeostasis yang baik selama stres oksidatif, sel mengeluarkan protein stres atau disebut juga heat shock protein (HSP) yang berfungsi melindungi sel dari kerusakan (Ekambaram, 2011). Salah satu jenis HSP yaitu HSP-70 (HSP dengan bobot molekul $70 \mathrm{kDa}$ ) yang beredar pada sirkulasi perifer wanita sehat yang sedang tidak hamil maupun wanita hamil. Namun, peningkatannya sangat signifikan pada wanita hamil dengan preeklampsia yang merefleksikan adanya inflamasi sistemik, stres oksidatif dan juga cedera hepatoseluler. Peningkatan kadar HSP-70, lebih signifikan pada wanita hamil dengan HELPP syndrome. Peningkatan kadar protein stres ini juga mengindikasikan adanya kerusakan jaringan dan tingkat keparahan khususnya pada pasien HELPP Syndrome 
(Molvarec et al., 2011). Senyawa HSP-70 merupakan penanda/marker stres oksidatif. Pada preeklampsia ekspresi HSP-70 lebih tinggi dibanding normal (Sheikhi et al., 2015).

Senyawa VEGF-121 rekombinan yaitu VEGF eksogen, yang merupakan protein proangiogenik yang berperan terhadap proses vaskulogenensis dan angiogenesis, mempunyai reseptor di dinding endotel yaitu vascular endotelial growth faktor receptore-1 (VEGFR-1), dan VEGFR-1 dapat terikat lebih kuat terhadap sFlt-1. Pemberian VEGF rekombinan 121 menurunkan hipertensi dan memperbaiki lesi di renal pada binatang model preeklampsia yang diberi sFlt-1 berlebihan (Liu et al., 2013). Senyawa VEGF mempunyai efek secara langsung terhadap vasculature sistemik. Pemberian infus VEGF meningkatkan nitric oxide (NO) yang bekerja sebagai vasodilator pada arteria dan vena pada manusia dan juga meningkatkan prostaksiklin di vaskuler endotel. Senyawa VEGF berperan sebagai kontrol/-menurunkan tekanan darah dan meningkatkan NO, menurunkan proteinuria dan memperbaiki kerusakan endotel ginjal sehingga VEGF diharapkan dapat sebagai terapi pada preeklampsia. Senyawa VEGF merupakan faktor penting dalam vaskulogenesis, angiogenesis dan memproliferasi serta melindungi sel endotel. Ablasio dari VEGF menyebabkan kelainan vasculature pada plasenta dengan kematian janin pada hari ke10 hinggake-12. Inhibisi VEGF secara in vivo menyebabkan venestrated endotel seperti yang terjadi pada preeklampsia (Powe et al., 2011). Senyawa VEGF merupakan faktor angiogenik yang sangat kuat dan penting untuk keberlangsungan sel endotel dan merupakan marker pada disfungsi endotel sistemik, sehingga bisa merupakan target terapi/investigasi. Pada mencit percobaan yang dibuat kadar VEGF-nya menurun, menyebabkan hipertensi, proteinurin dan endoteliosis pada ginjal seperti yang terjadi pada preeklampsia. Hipoksia menyebabkan sFlt-1 meningkat pada perkembangan preeklampsia dan manipulasi kadar sFlt-1, VEGF atau keduanya diharapkan dapat sebagai intervensi terapi preeklampsia (George dan Granger, 2011).

Penelitian ini bertujuan untuk mengetahui peran VEGF-121 rekombinan terhadap ekspresi HSP-70 pada plasenta mencit model preeklampsia. Diharapkan VEGF dapat menjadi salah satu solusi terapi preeklampsia agar morbiditas dan mortalitas maternal maupun perinatal dapat diturunkan.

\section{METODE PENELITIAN}

\section{Hewan Percobaan}

Penelitian pada hewan percobaan menggunakan plasenta mencit yang memenuhi kriteria inklusi yaitu berasal dari mencit (Mus musculus) betina galur Swiss diperoleh dari Pusat Veteriner Farma (Pusvetma) Surabaya. Penelitian ini menggunakan mencit betina umur tiga bulan, sehat, dengan bobot badan 20-25 g. Besar sampel berdasarkan rumus replikasi dari Steel dan Torrie (Sulistyowati et al., 2010) adalah 30 sampel yang terbagi menjadi tiga kelompok masing-masing kelompok terdiri dari 10 sampel yaitu kelompok pertama (K1) mencit bunting normal, kelompok kedua (K2) mencit model preeklampsia, dan kelompok ketiga (K3) mencit model preeklampsia yang mendapat terapi VEGF 121 rekombinan. Pada hari ke-16 masa kebuntingan mencit, dari ketiga kelompok perlakuan, mencit-mencit tersebut dikorbankan nyawanya dan dilakukan pembedahan dan diambil plasentanya. Alasan pengambilan pada hari ke-16 adalah diasumsikan seperti kehamilan trimester kedua pada kehamilan manusia, karena pada trimester kedua manifestasi preeklampsia sudah muncul pada manusia.

Pada mencit percobaan dilakukan sinkronisasi birahi, mencit betina dewasa usia tiga bulan dengan bobot badan 20-25 g disuntik 5 IU hormon Pregnant More Serum Gonadotropin (PMSG), 48 jam kemudian disuntik 5 IU Human Chorionic Gonadotropin (hCG). Mencit betina yang sudah disinkronisasi birahi dikawinkan dengan mencit jantan umur tujuh bulan, dengan bobot \pm 60 g, 17 jam setelah dikawinkan mencit dapat didiagnosis bunting bila terdapat copulatory plug (sumbat vagina).

Pada hari ke-1 kebuntingan, seluruh sampel secara acak dibagi menjadi tiga kelompok, yaitu: kelompok mencit bunting normal (K1) 10 ekor dipelihara tanpa intervensi, mencit bunting model preeklampsia (pada hari ke-1 sampai dengan hari ke-4 kehamilan diberikan anti Qa-2 sebanyak 10 ng iv agar menjadi model preeclampsia (Sulistyowati et al., 2010). Sebanyak 20 ekor mencit dibagi dalam K2 dan K3. Pada hari ke-12 hingga hari ke-15 kebuntingan mencit pada kelompok K3 diberikan VEGF-121 rekombinan, dengan dosis $125 \mathrm{mg} / \mathrm{kg}$ BB satu kali. Pada hari ke-16 kehamilan mencit Mus musculus dilakukan terminasi pada ketiga kelompok. Tikus kemudian dieutanasia menggunakan ketamin dan 
dilanjutkan dengan nekropsi. Setelah rongga abdomen terbuka, plasenta diambil dan dimasukkan ke dalam pot yang sudah berisi netral buffer formalin 10\%. Kemudian dilakukan pemeriksaan imunohistokimia. Reagen/kit yang digunakan yaitu Kit anti Qa2 antibody (5K44), Kit recombinant VEGF 121 (Recombinant mouse) $125 \mathrm{mg} / \mathrm{kgBB}$ Xeno-free ${ }^{\mathrm{TM}}$. Pregnant More Serum Gonadotropin (PMSG) PG 600, Human Chorionic Gonadotropin ( $h C G$ ) Chorulon 1500 iu dan Kit HSP-70.

Penelitian dilakukan pada bulan FebruariMaret 2016 di Kandang Hewan Percobaan dan Laboratorium Biomedik, Fakultas Kedokteran Hewan, Universitas Airlangga, Surabaya.

\section{Imunohistokimia}

Pengambilan sampel preparat dilakukan pada plasenta mencit yang sebelumnya telah dibedah dan dilakukan blok parafin kemudian diberikan pewarnaan Hematoxylin Eosin (HE). Pembuatan preparat histologis dilakukan dengan cara organ plasenta difiksasi dengan menggunakan larutan netral buffer formalin 10\% kemudian dipotong dan dimasukkan ke dalam tempat specimen yang terbuat dari plastik. Selanjutnya dilakukan proses dehidrasi dengan alkohol konsentrasi bertingkat yaitu alkohol 70, 80, 90\%, alkohol absolute I, absolute II masing-masing dua jam. Lalu dilakukan penjernihan dengan xylol kemudian dicetak menggunakan parafin sehingga sediaan tercetak di dalam blok parafin dan disimpan dalam lemari es. Blok parafin tersebut kemudian dipotong tipis dengan ketebalan 5-6 $\mu \mathrm{m}$ menggunakan mikrotom. Hasil potongan diapungkan dalam air hangat bersuhu $60 \mathrm{Cp}$ untuk meregangkan agar jaringan tidak melipat. Sediaan kemudian diangkat dan diletakkan dalam gelas objek untuk dilakukan pewarnaan Hematoxylin dan Eosin (HE). Selanjutnya diperiksa di bawah mikroskop cahaya mixon eclip CY1 dengan pembesaran 1000 kali. Dilakukan pemeriksaan imunohis-tokimia untuk menilai ekspresi HSP70 dalam prosentase sel/lapang pandang.

\section{Analisis Data}

Data dianalisis secara semikuantitatif menurut metode Remmele yang sudah dimodifikasi, dengan memanfaatkan indeks skala Remmele (Immuno Reactive Score/IRS) (Halon et al., 2012) yang merupakan perkalian antara skor persentase sel immunoreaktif dengan skor intensitas warna pada sel immunoreaktif. Teknik analisis data yang digunakan dalam penelitian ini adalah uji statistika Kruskall-Wallis. Jika terdapat perbedaan yang bermakna maka dilanjutkan dengan uji Post Hoc Mann-Whitne, dengan kemaknaan sebesar 5\% $(\mathrm{p}<0,05)$. Kelayakan etik didapatkan dari komisi etik penelitian FKH Unair No. 419-KE, tanggal 18 Maret 2015

\section{HASIL DAN PEMBAHASAN}

Distribusi Ekspresi HSP-70 pada plasenta Kelompok Mencit Bunting Normal (K1), Mencit Model Preeklampsia (K2), dan Mencit Model Preeklampsia dengan Pemberian VEGF-121 Rekombinan (K3), disajikan pada Tabel 1.

Ekspresi HSP-70 pada K1 minimal 0,90 maksimal 3,20 dengan rataan $1,69 \pm 0,68$ per lapang pandang, kelompok K2 ekspresi HSP-70 minimal 2,40, maksimal 5,10 dengan rataan $3,50 \pm 0,95$ per lapang pandang. Adapun kelompok K3 ekspresi HSP-70 minimal sebesar 0,90 maksimal 3,50 dengan rataan $2,24 \pm 0,84$ per lapang pandang.

Rataan ekspresi HSP-70 pada plasenta Mencit Bunting Normal (K1), Model Preeklampsia (K2), dan Model Preeklampsia dengan Pemberian VEGF-121 Rekombinan (K3), disajikan pada Tabel 2 . Kedua kelompok berbeda secara bermakna pada nilai rataan ekspresi HSP-70 yaitu kelompok K1 dengan kelompok K2 $(p=0,00 ;<0,05)$, kelompok K2 dengan kelompok K3 ( $\mathrm{p}=0,00 ;<0,05)$ sedangkan kelompok K1 dan kelompok K3 ( $\mathrm{p}=0,16 ;>0,05)$. Hasil penelitian ini membuktikan bahwa VEGF 121 rekombinan berperan menurunkan ekpresi HSP-70 pada plasenta mencit model preklamsia.

Perbandingan imunohistokimia ekspresi HSP-70 di plasenta Mencit Hamil Normal (K1), Model Preeklamsia (K-2), Model Preeklamsia dengan pemberian VEGF 121 Rekombinan (K3), disajikan pada Gambar 1. Ekspresi HSP-70 tidak tampak gambaran kromogen yang dominan sebagai penanda ekspresi HSP-70 di endotel plasenta mencit bunting normal (K-1), sedangkan pada (K-2) dan (K-3) dari pemeriksaan immunohistokimia tampak gambaran kromogen (penunjuk dengan panah putih) yang menunjukkan ekspresi HSP-70 pada endotel plasenta mencit, dan pada gambaran kromogen pada K-2 (endotel plasenta mencit hamil model preeklamsia) lebih dominan sebagai tanda ekspresi HSP-70 yang meningkat pada preeklampsia dibandingkan dengan K-3 (endotel plasenta mencit bunting model preeklamsia 
Tabel 1. Distribusi Ekspresi HSP-70 pada plasenta Kelompok Mencit Bunting Normal (K1), Mencit Model Preeklampsia (K2), dan Mencit Model Preeklampsia dengan Pemberian VEGF-121 Rekombinan (K3)

\begin{tabular}{cccccc}
\hline Variabel & $\mathrm{N}$ & Min & Max & Rataan & $\begin{array}{c}\text { Simpangan } \\
\text { baku }\end{array}$ \\
\hline K1 & 10 & 0,90 & 3,20 & 1,69 & 0,68 \\
K2 & 10 & 2,40 & 5,10 & 3,50 & 0,95 \\
K3 & 10 & 0,90 & 3,50 & 2,24 & 0,84 \\
\hline
\end{tabular}

Tabel 2. Rataan ekspresi HSP-70 pada plasenta Mencit Bunting Normal (K1), Model Preeklampsia (K2), dan Model Preeklampsia dengan Pemberian VEGF-121 Rekombinan (K3)

\begin{tabular}{lcccc}
\hline Variabel & $\mathrm{K} 1(\mathrm{n}=10)$ & $\mathrm{K} 2(\mathrm{n}=10)$ & $\mathrm{K} 3(\mathrm{n}=10)$ & $\mathrm{p}$ \\
\hline $\begin{array}{l}\text { Ekspresi HSP-70 } \\
\text { (prosentase sel/ lapangan }\end{array}$ & $1,69 \pm 0,68$ & $3,5 \pm 0,95$ & & 0,00 \\
pandang) & $1,69 \pm 0,68$ & $3,5 \pm 0,95$ & $2,24 \pm 0,84$ & 0,00 \\
\hline
\end{tabular}

Keterangan Signifikansi* $\mathrm{p}<0,05$
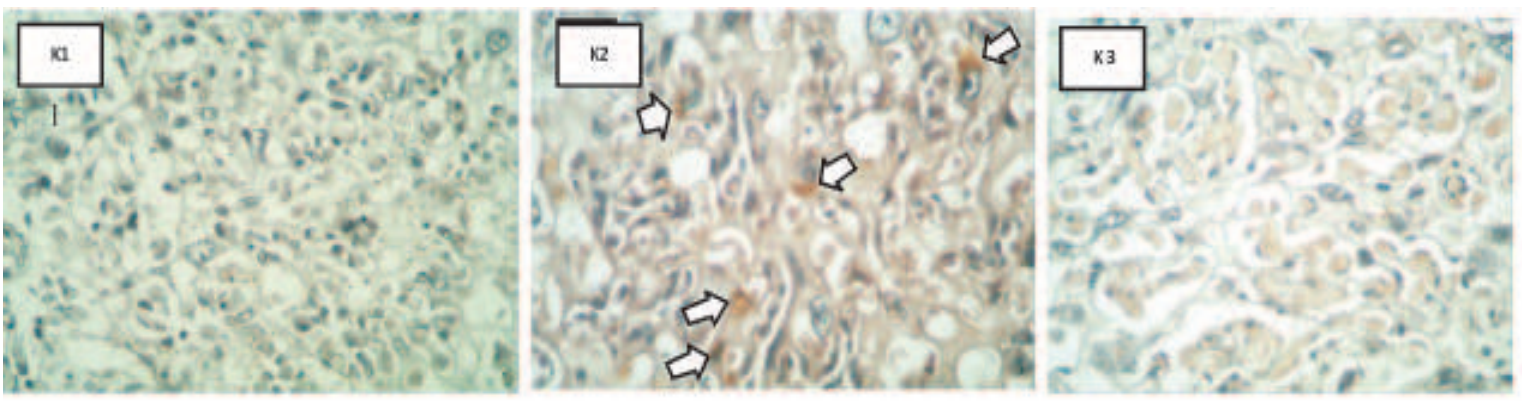

Gambar 1. Perbandingan imunohistokimia ekspresi HSP-70 di plasenta Mencit Hamil Normal (K-1), Model Preeklamsia (K-2), Model Preeklamsia dengan pemberian VEGF 121 Rekombinan

dengan pemberian VEGF 121 rekombinan yang ekspresi HSP-70 nya lebih rendah).

Pada preeklampsia, stres oksidatif terjadi pada plasenta maupun di sirkulasi maternal. Debris plasenta pada preeklampsia juga meningkatkan stres oksidatif yang menyebabkan disfungsi endotel. Mikropartikel yang beredar berhubungan dengan sFlt-1 yang ada di sirkulasi maternal (Powe et al., 2011). Adanya aktivitas stress, maka organ akan merespons agar sel tetap hidup dengan mempertahankan homeostasis dengan cara menginduksi enzim antioksidan yang kuat atau HSP yang akan melindungi sel. Senyawa HSP dapat menghambat ROS pada intraseluler (Ekambaram, 2011). Stres oksidatif menyebabkan meningkatnya kadar HSP-70 yang merupakan respons dari stres protein. Pada preeklampsia adanya stres protein pada plasenta menyebabkan HSP70 meningkat ekspresinya untuk memproteksi dan mempertahankan kehidupan sel dari apoptosis karena stress (Sahin et al., 2015). Senyawa HSP-70 sangat tinggi kadarnya pada preeklampsia early onset. Senyawa HSP-70 pada preeklampsia dan hamil normal berbeda secara signifikan pada tiap usia kehamilan sehingga HSP-70 tidak hanya sebagai marker preeklampsia tetapi juga berperan dalam patogenesis preeklampsia (Muller dan Schiffer, 2014).

Pada penelitian ini rataan ekspresi HSP70 kelompok bunting normal 1,69 $\pm 0,68$, kelompok preeklampsia 3,50 $\pm 0,95$ dengan $\mathrm{p}=0,00$ yang menunjukkan bahwa ekspresi HSP-70 
pada preeklampsia meningkat signifikan dibanding dengan normal. Rataan ekspresi HSP70 pada preeklampsia dengan terapi VEGF 121 rekombinan $2,24 \pm 0,84$ dengan $\mathrm{p}=0,00$ yang membuktikan bahwa terapi VEGF-121 rekombinan berperan menurunkan ekspresi HSP-70 di plasenta mencit model preeklampsia.

Laporan penelitian ini sejalan dengan laporan penelitian yang dilaporkan oleh Ekambaram (2011) yaitu pada preeklampsia HSP-70 meningkat baik dalam serum maupun plasenta karena berperan melawan stres oksidatif yang terjadi. Senyawa HSP-70 adalah protein terinduksi stres yang memainkan peran penting pada mekanisme pertahanan terhadap agen yang memacu cedera oksidatif, mencegah agregrasi protein yang terinduksi stres seperti yang terjadi pada preeklampsia.

Vascular endothelial growth factor (VEGF)121 rekombinan merupakan VEGF eksogen yang mempunyai peran terhadap proses vaskulogenesis dan angiogenesis yang mempunyai reseptor di dinding endotel yaitu VEGFR-1. Pemberian VEGF-121 rekombinan sebagai pengobatan preeklamsia pada hewan coba memiliki kemampuan menurunkan kadar sFlt-1 dalam sirkulasi darah, secara klinis menurunkan tekanan darah, secara histopatologis menunjukkan adanya perbaikan fungsi endotel, dan mengurangi hipoksia plasenta (Li et al., 2007; Mateus et al., 2011). Terapi VEGF-121 rekombinan bisa menetralisasi peningkatan sFlt-1 pada preeklampsia, sehingga kadarnya menurun dan fungsi angiogenesis kembali normal (Maynard dan Karumanchi, 2011). Terapi VEGF-121 pada tikus model preeklampsia mempunyai efek menurunkan tekanan darah, memperbaiki albumin, kreatinin, histologi plasenta, dan endoteliosis glomeruler (Li et al., 2007).

Fungsi VEGF yaitu menginduksi matrix metalloproteinase, meregulasi angiogenesis, limfangiogenesis, hematopoisis dan signaling sel (Muller dan Schiffer, 2014). Antiangiogenik sFlt-1 berasal dari plasenta yang mengalami hipoksia. Senyawa VEGF berinteraksi dengan sFlt-1 pada membran sel dan dapat menurun kadarnya bila sFlt-1 meningkat (Sahin et al., 2015). Pada preeklampsia terjadi insufisiensi plasenta yang menyebabkan hipoksia/iskhemi yang sangat krusial pada proses penyakit ini. Respons dari hipoksia plasenta yaitu meningkatnya sFlt-1 dan ROS (George dan Granger, 2011).
Maynard et al. (2011) dalam laporannya menyatakan bahwa pemberian terapi VEGF 121 rekombinan dapat menetralisasi efek dari peningkatan sFlt-1 pada preeklampsia sehingga pengikatan sFlt-1 ke faktor proangiogenik dapat menurun dan fungsi angiogenesis dapat kembali normal. Pendapat ini sejalan dengan Shah (2007) yang menyatakan bahwa VEGF 121 rekombinan, yang merupakan protein proangiogenik berperan terhadap proses vaskulogenensis dan angiogenesis dan mempunyai reseptor pada dinding endotel yaitu VEGFR-1. Senyawa VEGFR-1 dapat terikat lebih kuat terhadap sFlt-1. Pengobatan dengan pemberian VEGF 121 rekombinan memiliki kemampuan menghambat sirkulasi sFlt-1 dalam darah, menurunkan tekanan darah maternal, perbaikan fungsi endotel, dan mengurangi hipoksia plasenta.

Senyawa VEGF memiliki beberapa reseptor yaitu VEGFR-1 atau dikenal juga dengan Flt-1, VEGFR-2, Tie-1, dan Tie-2. Reseptor-reseptor ini juga memiliki peran penting dalam perkembangan vaskuler plasenta. Perubahan regulasi dan signaling pada jalur angiogenik awal gestasi juga membantu terjadinya invasi sitotrofoblas yang tidak adekuat seperti yang terlihat pada preeklampsia. Pada manusia, ligand dan reseptor VEGF diekspresikan dalam kadar tinggi oleh jaringan plasenta pada trimester pertama. Pada preeklampsia, terjadi perubahan pada invasi sitotrofoblas terkait VEGF, PIGF, dan Flt-1 (Young et al., 2010).

Senada dengan hal tersebut, Warington et al. (2013) memaparkan pada kondisi plasenta yang iskemik pada mencit adalah sebagai suatu akibat dari adanya penurunan tekanan perfusi uterus, maka akan terjadi peningkatan sFlt-1 dan penurunan secara drastis kadar VEGF bebas pada sirkulasi. Seperti yang dilaporkan juga bahwa pemberian infus VEGF121 pada plasenta mencit yang iskemik akan mengembalikan tingkat GFR dan fungsi endotel, sehingga tingkat iskemik pada plasenta dan juga tekanan darah akan menurun.

Kadar HSP-70 pada mamalia dapat diturunkan atau dihambat dengan pemberian senyawa agonis HspA12B yaitu suatu senyawa growth factor dari VEGF, sehingga kerusakan sel dapat dicegah pada endotel yang masih sehat dan juga dapat mencegah semakin banyaknya sel yang akan mengalami apoptosis. Kadar HSP-70 yang timbul sebagai mekanisme pertahanan pada sel endotel yang 
rusak seperti pada preeklampsia dengan pemberian agonis HspA12B dari VEGF kadarnya tidak meningkat secara signifikan (Sukhatme et al., 2012).

\section{SIMPULAN}

Senyawa VEGF-121 rekombinan berperan menurunkan ekspresi HSP-70 pada plasenta mencit model preeklampsia.

\section{SARAN}

Senyawa VEGF 121 rekombinan dapat disarankan untuk diaplikasikan sebagai terapi preeklampsia pada manusia melalui tahapan uji klinis.

\section{UCAPAN TERIMA KASIH}

Ucapan terima kasih kepada Kepala Laboratorium Reproduksi Veteriner, FKH, Unair yang telah memberikan fasilitas pemakaian laboratorium serta berbagai pihak yang tidak dapat disebutkan satu persatu, yang telah membantu serta memberi dukungan atas terlaksananya penelitian ini.

\section{DAFTAR PUSTAKA}

Ekambaram P. 2011. HSP70 Expression and its Role in Preeclamptic Stress. Indian $J$ Biochem Biophys 48(4): 243-55

George EM, Granger JP. 2011. Mechanisms and Potential Therapies for Preeclampsia. Curr Hypertens Rep 13(4): 269-275.

Ghulmiyyah L, Sibai B. 2012. Maternal Mortality From Preeclampsia/ Eclampsia. Semin Perinatol 36(1): 56-59

Halon A, Donizy P, Biecek P, Rudno-Rudzinska J, Kielan W, Matkowski R. 2012. HER-2 Expression in Immunohistochemistry Has No Prognostic Significance in Gastric Cancer Patients. Scientific World Journal 2012: 941259

Han L, Yang Z, Li K, Zou J, Li H, Han J, Zhou L, Liu X, Zhang X, Zheng Y, Yu L, Li L. 2014. Antepartum or Immediate Post- partum Renal Biopsies in Preeclampsia of Pregnancy: new Morphologic and Clinical Findings. Int J Clin Exp Pathol 7(8): 51295143.

Hansson SR, Nääv ̊̊, Erlandsson L. 2015. Oxidative stress in preeclampsia and the role of free fetal hemoglobin. Front Physiol 13(5): 516

Li Z, Zhang Y, Ying Ma J, Kapoun AM, Shao Q, Kerr I, Lam A, O'Young G, Sannajust F, Stathis P, Schreiner G, Karumanchi SA, Protter AA, Pollitt NS . 2007. Recombinant Vascular Endothelial Growth Factor 121 Attenuates Hypertension and Improves Kidney Damage in a Rat Model of Preeclampsia. Hypertension 50: 686-692.

Liu H, Hou F, Liang H, Liu G, Li Y. 2013. Effects of diagnostic ultrasound on HSP70 expression in chorionic villi in rats during early pregnancy and the role of HSP70 in apoptosis in chorionic villi. International Journal of Molecular Medicine 32(5): 10851092

Mateus, J, Bytautiene, E, Lu, F, et al. 2011. Endothelial growth factor therapy improves preeclampsia-like manifestasions in a murine model induced by overexpression of sVEGFR-1. Am J Physiol Heart Circ Physiol 301: H1781-1787.

Maynard SE, Karumanchi SA. 2011. Angiogenic Factors and Preeclampsia. Semin Nephrol 31(1): 33-46

Molvarec A, Szarka A, Walentin S, Beko G, Karadi I, Prohaszko Z, Riqo J Jr. 2011. Serum heat shock protein 70 levels in relation to circulating cytokines, chemokines, adhesion molecules and angiogenic factors in women with preeclampsia. Clin Chim Acta 412(21-22): 1957-1962

Müller-Deile, Schiffer M. 2014. Preeclampsia from a renal point of view: Insides into disease models, biomarkers and therapy. World J Nephrol 3(4): 169-181

Powe CE, Levine RJ, Karumanchi SA. 2011. Preeclampsia, a Disease of the Maternal Endothelium The Role of Antiangiogenic Factors and Implications for Later Cardiovascular Disease. Circulation 123(24): 2856-2869 
Sahin H, Gunel T, Ali, Benian A, Ucar EO, Guralp O, Kilic A. 2015. Genomic and proteomic investigation of preeclampsia. Exp Ther Med 10(2): 711-716

Shah DM. 2007. Preeclampsia: new insights. Curr Opin Nephrol Hypertens 16(3): 213 220.

Shamsi U, Saleem S, Nishter N. 2013. Epidemiology and risk factors of preeclampsia; an overview of observational studies. Al Am een J Med Sci 6(4): 292-300

Sheikhi A, Razdar S, Rahmanpour H, Mousavinasab N, Ganji HB, Jafarzadeh A. 2015. Higher expression of HSP70 and LOX-1 in the placental tissues of preeclampsia pregnancies. Clin Exp Hypertens 37(2): 128-135

Sukhatme VP, Zon LI, Galloway J. 2012. Methods and Compositions For The Treatment And Diagnosis Of Endothelial Cell Disorders And Angiogenic Disorders. https:/ /docs.google.com/viewer?url=patentimages. storage.googleapis.com/pdfs/US8329175.pdf.

Sulistyowati S, Abadi A, Hood J, Soetjipto. 2010. The Influence of Low HLA-G Protein Expression on HSP-70 and VCAM-1 Profile in Preeclampsia Indonesian J Obstet
Gynecol. Indones J Obstet Gynecol 34(4): 185-190.

Sulistyowati S, Soetrisno, Kartika NH. 2016. Ekspresi Human Leukocyte Antigen-C di Trofoblas dan Natural Killer Cell di Desidua pada Preeklampsia Berat. Jurnal Kedokteran Brawijaya 29: 59-63

Tal R. 2012. The Role of Hypoxia and HypoxiaInducible Factor-1Alpha in Preeclampsia Pathogenesis. Biology of Reproduction 134: $1-8$

Warrington JP, George EM, Palei AC, Spradley FT, Granger JP. 2013. Recent Advances in Hypertension: Recent Advances in the Understanding of the Pathophysiology of Preeclampsia. Hypertension 62(4): 666-673.

Young BC, Levine RJ, Karumanchi SA. 2010. Pathogenesis of Preeclampsia. Annu Rev Pathol Mech 5: 173-192.

Zeisler H, Llurba E, Chantraine F, Vafish M, Staff AG, Sennsfrom M, Olovsson M, Brennedeoke SP, Stepan H, Allegranza D, Diiba P, Schoedi M, Hund M, Verlohren S. 2016. Predictive Value of the sFlt-1:PlGF ratio in women with suspected preeclampsia. $N$ Engl J Med 374: 13-22. DOI: 10.1056/ NEJMoa1414838 